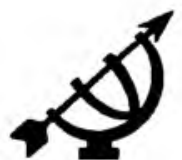

\section{Complex equality - some notes on redistribution in South Africa}

\author{
Pieter Coetzee \\ Department of Philosophy \\ UNISA \\ PRETORIA \\ E mail: coetzph@alpha.unisa.ac.za
}

Abstract

Complex equality - some notes on redistribution in South Africa

In this article I attempt to show that a theory of redistribution can be derived from Walzer's political theory as presented in his Spheres of justice. I argue that this theory shows in what areas of South Africa's public life redistribution is required, and what patterns of redistribution should be followed. Walzer's political theory leans heavily on the notion of shared understandings. In South Africa there are many areas of public life in which interpretations of these understandings are in conflict. I attempt to identify these areas and to show what premisses underlie the conflicting interpretations.

\section{Stating the problem}

Michael Walzer defends a system of "complex equality" which has significance for attempts in S.A. to distribute social goods (including, and particularly income and wealth) equitably and fairly. Complex equality is a political dispensation governing the distribution of social goods in differentiated societies (i.e. societies which produce and distribute a large variety of social goods in accordance with culturally determined patterns of distribution). Complex equality is characterized by a strict equality of access to the social goods of all spheres of society (moral and material) - an equality which is maintained alongside different patterns of distribution for each sphere. This dispensation is designed to resist domination. To understand Walzer's concept of domination we begin by accepting his distinction between monopoly and dominance. When someone or some group has a monopoly, they have control over the production and distribution of some social good. Dominance results when those who hold a monopoly use their control over the social good in question to gain control over other social goods. So, for instance, anyone who holds a monopoly of state 
power could use this position to gain control over the means of production. Walzer believes that monopolies are in themselves not unjust; it is only when monopolies are used to aspire to positions of dominance that unjust distributions arise. Under a system of complex equality, monopolies could grow within spheres, but no one could convert a monopoly in one sphere into control over the social goods of another sphere. But since the distribution of one social good will affect another in another sphere, there can, in practice, only be relative autonomy for spheres - but even relative autonomy is, for Walzer, a critical principle of complex equality.

- A sphere is absolutely autonomous only when the distributive pattern of other spheres do not impinge upon it; a sphere is relatively autonomous only when an agent's monopoly in one sphere does not give her a monopoly in another sphere (i.e. seepage and interpenetration between spheres do in fact occur, though this does not give any individual cross-boundary advantages).

Walzer thinks that monopolies cannot be prevented though dominance can. Systems of "simple equality", which recognize an equality of regard and/or outcome in various ways as the principles of fair distribution in all spheres of social life, attempt to deal with monopolies by outlawing them - a move Walzer views as profoundly self-defeating. Rather than attacking monopoly, thinks Walzer, we should devise a social system which resists dominance.

Now, in South Africa a problem of domination had manifested itself during the apartheid era. The white sector of the population had thrived economically in part because they had control over the political sphere of social life. And this situation has given them competitive advantage over other people in the current market. As I read Walzer, this historically gained advantage is unjust because it is due to boundary crossings between spheres, and to an exclusive admissions policy with regard to membership of the 'South African' community. Wealth gained because of these things should be the subject of redistribution, especially since the white sector of the population still controls the greater share of the nation's wealth.

I shall attempt to indicate that Walzer offers reasons why a redistribution should be carried out. According to Walzer historically gained advantages are unjust if due to exclusionary membership policies. As I shall attempt to show, the normative dimension of membership, taken together with an attempt to structure society in a way which resists domination - particularly through the prohibition on boundary crossings between spheres - require a redesign of society if advantages were accumulated because of domination. I shall attempt to exploit these points in making a case for redistribution. 


\section{Walzer's theory}

Walzer defends a form of communitarian pluralism. He attempts to reinterpret notions of freedom and equality in an effort to construct a theory of distribution suitable for multi-cultural societies (though he particularly has the USA in mind). His attempt at reinterpretation centres in three significant features of his political theory:

- In practice liberty and equality are best defended by separating the political sphere of social life from all other spheres, in particular the economic sphere, and

- recognizing that each sphere has its own pattern or principle of distribution which conforms to the shared understandings of the political community within which the pattern is manifest;

- each sphere functions autonomously, but the political sphere has an umbrella function - it has to ensure that no distributive transgressions take place between spheres (eg. the fact that you are rich and I am poor does not give you any competitive advantage if both of us are running for public office).

Domination in social life is best combatted by maintaining the autonomy of each sphere of distribution - by preventing those who have great economic power from acquiring political power because they have economic clout, and vice versa; or by preventing those who have religious power from obtaining control over the sphere of education because they have influence in the sphere of religion. Since the boundaries between spheres reflect a cultural bias (where they are drawn may vary from society to society), the account of justice which Walzer presents is ultimately a cultural account.

\subsection{First principles and starting point}

\section{Particularism and pluralism}

The perspective or vantage point Walzer thinks is necessary for the acquisition of political knowledge is the shared understandings of one's own society, and this is the perspective Walzer adopts in Spheres of justice (1983). Walzer identifies his starting point as particularist and pluralist. His particularist standpoint is inspired by his belief that principles of justice have to be based squarely on the shared understandings of one's own society. Walzer (1983:xiv) says he intends to "stand in the cave, in the city, on the ground" the goal being "to interpret to one's fellow citizens the world of meanings ... [they] share". This approach contrasts with one in which theorists wish "to walk out of the cave, leave the city, climb the mountain, fashion for oneself (what can never be fashioned for ordinary men and women) an objective and universal standpoint". 
Walzer operates with two senses of "pluralist". One sense relates to the differentiation of patterns of distribution between the spheres of justice in Walzer's society (the USA). The second sense connects with the account of "particularist" given above. Thigpen (1984:135) describes it as the "view that distributive principles are particular, not universal, that different principles are appropriate for different kinds of societies". This view of (distributive) justice may be described as perspective-driven.

\section{Justice can only be found from the vantage point of shared understandings}

A comprehensive view of society underwrites this very important principle. Human society is a "distributive community" (Walzer, 1983:3) i.e. a community in which people create goods (moral and material) which they share, divide and exchange, and in which distribution is the most significant vehicle or medium of social (interpersonal) relations. The goods of a community's moral and material worlds (goods like rights, justice, equality, membership, work, leisure, education, honours) are social because their meanings are socially shared and defined and because they are conceived and created through social processes. No single set of (primary) goods extends across all moral and material worlds, because the meaning of social goods are historical (the product of particular understandings built up over time) and relative (the social meanings that constitute goods can vary across time and space), and because different social processes lead to different understandings of goods (i.e. how they should be distributed and for what reasons).

\section{Relativism}

Just how deep the relativism of Walzer's historical pluralism runs, may be gauged by the following consideration. Meaning and distribution are conceptually linked to understand what a good means to the people for whom it is a good is to understand how the good in question is actually distributed in the community. Since social meanings are distinct, there must be a plurality of social goods, and, in particular, a plurality of lists of primary social goods which will differ from society to society. Differentiated societies, then, have distinctive social meanings with distinctive social goods. (In the case of the USA, Walzer mentions and discusses the following social goods: membership, security and welfare, money and commodities, office, hard work, free time, education, kinship and love, divine grace, recognition and political power). Each social good constitutes a distinct distributive sphere within which only certain (culturally biased) arrangements and criteria are appropriate. Given this the following become noteworthy:

- the principles of justice (for the USA and other differentiated societies) must be pluralistic:

Different social goods ought to be distributed, for different reasons, in accordance with different procedures, by different agents; and ... all these differences derive from different understandings of the social goods 
themselves - the inevitable product of historical and cultural particularism (Walzer, 1983:6).

- pluralism must be protected - nobody should be allowed to convert a monopoly of one social good into control of another i.e. nobody should be allowed a position of dominance. Walzer expresses this in the form of a principle:

No social good $\mathbf{x}$ should be distributed to men and women who possess some other good $y$ merely because they possess $y$ and without regard to the meaning of $x$ (Walzer, 1983:20).

Walzer underwrites the idea of a "pluralist" community which requires structures that unite all member communities by institutional bonds. In Walzer's sense the good society is one in which a variety of members (or partial) communities coexist in a form of parallelism, all enjoying equal recognition, (constitutionally) guaranteed. The good community is more than just an association of member groups, for they share an understanding of what is public (of concern to all members) and what is private (of concern to particular member groups) within a broad constitutional framework. This conforms to a basic principle of political community: it is the understanding people share that makes them into a community and not just an association. The understanding they share - in the "pluralist" sense - is that there are matters of public concern about which consensus must be established before any line of political action can become possible. The roots of political community is implicit in this idea: there are issues which anyone can legitimately take an interest in - to the point of censuring state conduct - and this concerns the maintenance of the separation between public and private, and the confinement of state authority to the former. The line separating the domains will - in any democratic society - be open to negotiation in a public forum of debate. So where the line is drawn is to a large extent a function of cultural particularism.

\subsection{Shared understandings and common life}

\subsubsection{Political theorizing as interpretations of shared understandings}

\section{The particular and the universal}

Walzer's approach to questions of distributive justice is marked by a tension between the dues of particularity and universality. The shared understandings of our common life underpin our principles of distribution. A society is just "if its substantive life is lived ... in a way faithful to the shared understandings of the members ... [This means that] ... every substantive account of distributive justice is a local account" (Walzer, 1983:313-314). For every community, argument "in matters of morality, simply is ... appeal to common meanings" (Walzer, 1983:29) Yet, we do justice to all by "respecting their particular creations" (Walzer, 1983:314). Justice requires a deep respect for the social meanings of different peoples: justice "cannot require a radical redesign of the village [community] 
Complex equality: some notes on redistribution in South Africo

against the shared understandings of the members. If it did, justice itself would be tyrannical" (Walzer, 1983:313).

\section{The principle of authoritive interpretation}

Walzer's comprehensive theory of society attempts to pay all dues. For instance, he argues that in the USA the distributive logic of the sphere of security and welfare, need rather than the ability of patients to pay, must be the operating principle. Walzer claims that his arguments are supported by polling data and that a majority opinion (a strong consensus) would justify a political practice. Bell (1993:63) interprets Walzer's notion of shared meaning an "an authoritative interpretation of community morality that bears on the proper character of the community". There are two versions of what counts as an "authoritative interpretation" of community morality - a strong and a weak one. Bell (1993:63 ff) affirms the weak version. The weak version requires

... that there be substantial agreement about the meaning of a social good (i.e. how it should be distributed and for what reasons), that this agreement reflect the considered judgement of a large majority of members, and that there be general recognition that the good in question is consistent with the common good of the community.

Walzer (1983:8) endorses a strong version. In addition to the above, it requires "that members affirm that their (moral) identity is affirmed by the community's consensus regarding the value of the good in question. ... Men and women take on concrete identities because of the way they conceive and create, and then possess and employ social goods". If strong majorities show support for a certain interpretation of a shared meaning, then that is strong evidence for the interpretation. Walzer thinks it is a virtue of his approach - keeping his nose close to the ground and interpreting to his fellow citizens their shared meanings - that his arguments can be empirically evaluated.

\section{A comprehensive theory of society}

The drive towards universality is especially encouraged by Walzer's reliance on a comprehensive theory of society. Critical standards aspire to universality - yet they are in fact the product of particularity. Critical standards are made available by the shared meanings of the community. This means that whenever a dissenter criticises a particular social practice, she is protesting in the name of the community itself (because it is unfaithful to its own self-understanding). She is appealing to a different interpretation of the meaning of the practice - which interpretation may arise within the culture of the community itself (immanent criticism), or may be borrowed from another culture (trans-acculturation). Substantive differences between interpretations of the common good are encouraged by a culture of dialogue, but no appeal beyond the community itself can establish which interpretation will become dominant: that is a matter for the members themselves to decide. 
Walzer endorses the view that standards of criticism and rational justification are context bound, part of the consciousness of particular communities. He, however, thinks there are trans-communal grounds of social critique which are part of particular communities' histories and traditions. In Interpretation and social criticism (1987) Walzer develops the idea of trans-communally shared prohibitions, which are "products of many people talking of real if always tentative, intermittent and unfinished conversations. We might think of them not as discovered or invented but rather as emergent prohibitions, the work of many years, of trial and error, of failed, partial and insecure understandings" (Walzer, 1987:24).

The possibility of a critique rooted in particularities yet having universal import proceeds from the convergence of people's understanding of core moral propositions. Every society has prohibitions on things like murder, gross cruelty and torture. These are trans-cultural goods i.e. goods for all communities, whatever their cultural diffrerences. It is possible to extract a core of prohibitions from these goods and to ground morality on it. Dissenters' criticism draws on this core to criticise fellow members of their community, i.e. they draw on a world of shared meanings rooted in the social life of human beings. For Walzer there is no court of appeal beyond the morality of actual communities.

Referring to Walzer, Bell argues that dialogue aimed at securing consensus regarding shared prohibitions represents a gain in (moral) self-understanding. The test is simple enough: " there can be progress from position $\mathrm{x}$ to position $\mathrm{y}$ if the transition from $x$ to $y$ can be shown to represent a gain in understanding, whereas a similarly plausible narrative of a possible transition from $y$ to $x$ couldn't be constructed" (Bell, 1993:76). And he continues (1993:77):

I imagine that a plausible narrative can be constructed to show that a transition from ... Nazi morality ... to a morality which prohibits gross cruelty represents moral growth, whereas this couldn't be done the other way around. So even a German brought up in a culture whose 'prevailing moral beliefs and intuitions' supported acts of gross cruelty against Jews, if she demonstrated this asymmetrical relationship between the 'prevailing moral beliefs and intuitions' of her community and another morality which prohibits gross cruelty, might well condemn that part of her community's morality which favours gross cruelty without appealing to an acontextual moral truth.

\subsubsection{The common life as standard of judgement}

If shared understandings express meanings (agreements about the distribution of social goods) which are accepted as just, how does a community rise to a critique of its own practices? Walzer (1983 and 1987) has suggested ways in which an immanent criticism is possible, but Walzer's views go much deeper. Whether or not we think of social meanings as just depends on how meanings are shared. Walzer argues that the proper attitude of mind underlying any accord of justice 
should be respect for "those deeper opinions that are the reflections in individual minds, shaped also by individual thought, of the social meanings that constitute our common life" (Walzer, 1983:320).

If Walzer is right, a common life exists only if people share in shaping that life. So, if shared values are not fully shared or imposed by domination, then a common life is indeed not possible. Downing and Thigpen (1986:457) reinforce this interpretation. Walzer, they say, argues "that a common life may deserve more or less respect and that the appropriate degree of respect should be determined by inquiry into the origin of social meanings". For a genuine common life to exist, members of a community must share in creating the social meanings. The communality of a given social order depends on its inclusiveness. Membership, as Walzer argues, is the first condition of participation in the creation of the commonality, and it must therefore be distributed equally. Downing and Thigpen (1986:417) formulate the critical edge that this gives to social criticism as follows:

The concept of the common life ... becomes a standard when a criterion justifying respect for shared understandings is introduced. This standard of judgement can be applied ... by citizens who have assumed that they share a common life. Their discovery of forms of domination that exclude them from the common life should lead them (without resort to an external vantage point) to criticize their society.

It is crucial to note that the potential for dissent is built into the very fabric of the society Walzer presents. The different (autonomous) spheres of distribution, each with its own appropriate principles or pattern of distribution, form the public domain of a differentiated society. The political sphere is charged with the task of policing boundary transgressions i.e. with the task of resisting and eliminating areas where domination may grow up. So, if prevailing understandings perpetuate a way of life that was institutionalized through domination, the distribution of power in that society has to be challenged, for such a distribution precludes the genuine sharing of a common life. If a people are to have a common life, the story of their culture must be one which everybody authors. Downing and Thigpen (1986:459) identify the sense in which equality of participation defines Walzer's idea of the good society.

[Walzer's] good society involves not simply equality of resources and social goods, but also equality of participation according to the criterion of pluralist citizenship, where citizens share in determining the meanings, values, and distributive principles for various social goods.

But this freedom to participate can be realized only if the spheres are (relatively) autonomous. Walzer's society can be called good - and just - only if social life in each sphere is governed by the appropriate pattern or principle of distribution. The political sphere has a special status; it has one proper role - to maintain the boundaries between other spheres and between itself and the others. An equality of consideration (though not of outcome) prevails within each sphere: equal citizenship means that members of a community receive equal consideration within each 
sphere with respect to the distributive principles which govern these spheres. This amounts to a guarantee of an equality of opportunity (a logical outcome of an equality of regard or consideration) within each sphere, which in turn amounts to a formal guarantee of equal liberty for all.

\section{The common life as normative standard}

Walzer's concept of the common life serves as a standard or norm against which the acceptability of moral/political actions are measured. If Downing and Thigpen (1986:417) are right, Walzer's community has a (developed) common life only to the extent that all have a share in shaping its commonality. Membership of the community is premissed on the recognition of all members as contributors to the shape that the culture of the community takes, i.e. it is premissed on the recognition of each member as a "culture-creating" creature. This idea of equality is constitutive of the inclusiveness of the common life. Domination of one group or class by another (in virtue of the dominant group's or class's control of some social goods, e.g. money or the means of production) works against inclusiveness in the sense that the dominated group or class receives less recognition than its peers in the sphere in which it is dominated (e.g. in education or housing). Domination is a ground for a critique of shared understandings, and, ultimately a critique of the unequal power relations which underpin those understandings. The inclusiveness of the common life, then, requires that asymmetrical power distributions be corrected.

According to Downing and Thigpen (1986:459) the concept of the common life, normatively understood, provides a basis for a critique of the abuse of political power, and so serves as a principle of legitimation. A pattern of distribution is legitimate if it accords with the social meaning of the good being distributed. Whoever controls power in the political sphere cannot, without injustice, use this power to determine the social meanings and patterns of distribution of the social goods in other spheres. It could, then, not be possible for those who have political power to determine the distribution of the social goods in disregard of the common understandings and social meanings which underpin their patterns of distribution. The separation of spheres and their (relative) autonomy, then, offers protection of equality of participation and of access to opportunity. The common life offers protection from domination because it is a protected sphere within which individuals can make uncoerced choices. An uncoerced choice is a choice made internal to a cultural structure. It is a choice made available by a culturally specified range of options. This includes the choice of a way of life. The good life is a conception developed collectively and persons understand their own good by participating in the creation of the commonality, which means a person's good cannot be determined singly by the individual alone in isolation from the social context in which she operates. The crucial point is that the common good remains overriding: no individual's good can trump or negate it. 


\section{The principle of need as principle of redistribution}

Now recall a point made earlier on. We said that a society is just if its common life is lived faithful to the common understanding of the members. By itself this criterion of justice can be used to legitimise societies in which social goods are hierarchically structured. Should justice require a radical redesign of such societies? Here we note the following.

- First, for Walzer actual distributions are regulated by a community's resources These resources are the past and present products of the community, the accumulated wealth of its members, and not some surplus portion of that wealth. If any group has been excluded from participation in the production and accumulation of wealth (perhaps because a hierarchical structure has grown up through the institutionalization of domination) it is just (fair) for them to demand a re-design of the sphere of income and wealth.

- Second, in the case of needed goods, communal provision opens the door to communal participation. Communal participation is one very important guarantee of the equal membership of all members. The significant feature about communal provision based on need (as in the Walzer's sphere of security and welfare) is that it is redistributive in nature. This means that wherever need applies as a principle of distribution (as in a society's primary list of basic needs) the accumulated wealth of a community should be distributed in accordance with the needs of individuals. Any good in the list of basic needs not distributed as indicated, constitutes an area of unfair treatment and requires a redesign of the sphere of distribution. If we interpret the common life as the arena in which need determines the pattern of distribution of a community's resources, we arrive at one of the most significant attributes of Walzer's community: (re)distribution creates a union - a sense of community - that transcends all differences of interest. In such a society debates about communal provision are, as Walzer notes (1983:12), at bottom, interpretations of this union.

Membership and protection against domination guarantees only an equality of access to opportunity and participation - not an equality of outcome. The difference is significant for our understanding of the normative dimensions of community. Communal provision in the sphere of needed goods is the most significant area in which redistribution is a requirement of justice. The redistribution of needed goods - goods like work, housing and education - will award greater shares to those who are more needy. Redistribution in this area will create the need for redistribution in other areas, for instance, in the sphere of income and wealth, but only if historical injustices have prevailed in the latter, injustices which have their genesis in exclusive admissions and membership policies, and in the failure of the political arm to protect certain groups from domination. 


\section{The justifiability of redistribution in South Africa}

Walzer's concept of the common life is crucial to the case for redistribution. An inclusive membership policy receives priority because members' status as equals qualifies them for equal consideration in each sphere in terms of the distributive patterns of each. The existence of a common life with borders between spheres and between different communities of character which political institutions protect is critical to Walzer's vision of the plural state. "Without ... [borders], there couldn't be communtties of character, historically stable, ongoing associations of men and women with some special commitment to one another and some special sense of their common life" (Walzer, 1983:62).

Communitarian society: the principles of provision, recognition and egalitarian reciprocity

Membership of the political community is important because of what members owe one another "and the first thing they owe is the communal provision of security and welfare" (Walzer, 1983:64). For each community of character the common life is the fundamental standard. This standard prohibits the exclusion of community members of character from participation in the common life of society at large: "the process of self-determination through which a democratic state shapes its internal life must be open, and equally open, to all those men and women who live within its territory, work in the local economy, and are subject to local law" (Walzer, 1983:60).

If there is to be a genuine community of citizens, then everyone within the political community - whatever their attachments to other historical/traditional communities may be - must be able to exercise full political rights. Walzer singles out "guest worker" policies in the European democracies for attention. If these countries are to be true to their basic understanding of themselves as democracies, they must abandon policies which violate this understanding. A similar imperative applied to South Africa. The exclusion of black people from certain territory in South Africa (under the Land Act of 1913), and their exclusion from central business districts in the main metropolitan areas, could not - if Walzer is right - be justified with reference to the protection of communities of character, for a political community exists "for the sake of provision, provision for the sake of community: the process works both ways, and that is perhaps its crucial feature" (Walzer, 1983:64). Exclusion conflicts with the principle of provision: white control of the economic sphere reduced black people to the status of "guest workers" in territory reserved exclusively for whites (under the so-called "migrant labour" system) in which they enjoyed no rights to political representation.

The principle of provision rests on the principle of egalitarian reciprocity, which is the foundation of an inclusive common life.

Every political community must attend to the needs of its members as they collectively understand those needs ... the goods that are distributed must be 
distributed in proportion to need, and ... the distribution must recognize and uphold the underlying equality of membership (Walzer, 1983:84).

Witness how the distribution of hard work - a basic or primary good - provides a good example of the social critique generated by the common life standard. Hard work as a social good is largely distributed by the market, which, because of the common life standard, requires that work be available to all, and that no work be treated as degrading. In apartheid S.A, gruelling/dirty work was distributed as a negative good which degraded black people and barred them from the right to share in the common life. Walzer's emphasis on the distribution of hard work as a needed good is part of the emphasis he places on the need for all to participate in the common life and hence to be full members of the community. In this regard Downing and Thigpen (1986:468) note that the "integrity of the common life ... constitutes a standard for the distribution of hard work". It is not difficult to see that Walzer succeeds in addressing the historical problem of disadvantage due to exclusion and dominance (boundary crossings). And it is not difficult to see that a theory justifying redistribution in cases of historical injustice can be derived from Walzer's views. Walzer's comprehensive theory of the common life endorses the idea of community understood as (re) distributive in nature. In what follows I attempt to show in what ways current South African conditions are susceptible to critique from Walzer.

\subsection{Redistributing social goods in contemporary South Africa}

We must bear in mind Walzer's avowed aim to formulate principles of distribution which can be used to criticize practice, should practice be at variance with selfunderstanding. Bearing in mind that different societies have different lists of basic or primary goods, the distributive principles currently operative in South Africa are plural - different principles are recognized for different spheres - though they are not always consistent with current self-understandings.

\section{Recognition of difference in South Africa}

Membership of the political community is currently guaranteed for every member of a community of character. To this extent the political community has experienced a redesign. But though the principle of pluralism has been entrenched in the constitution - both as a principle of distribution based on need in critical areas of the common life (such as health care), and as a strategy for playing the politics of recognition (this principle recognizes cultural diversity), communities of character are given recognition only as linguistic communities, and no specific group rights exist which protect their cultural life. The absence of the latter is no doubt due to the racist legacy of enforced group membership. This legacy is unfortunate since redistribution requires recognition of difference. Recognition of communities of character is crucial to the social critique which Walzer mounts in two senses: the boundaries between spheres and the principles of distribution appropiate to them are judged in terms of the goal of a common life which answers 
to a specific self-understanding; the moral acceptability of patterns of distribution depends on the way in which shared values are generated, and in this regard a strict equality with repect to membership is decisive.

\section{Group rights}

What do South African citizens owe one another if they are to have an inclusive common life? At minimum they owe one another recognition of who they are and where they come from. And this requires protection of groups per se against the assimilationist tendencies of dominant cultures. In Spheres of Justice Walzer is not explicit on this point. I thus turn to the views of a Walzerian-minded thinker - $M$. McDonald - to show what is involved here. If redistribution is to make a substantive difference we should begin by distinguishing between "a group's having a right [specifically pertaining to language and education] and its members having that right" (McDonald, 1991:218). Following McDonald, a group right protects interests which are not severable into individual interests - interests whose protection benefit a group itself by providing a collective benefit. So, for example, protecting a group's right to be educated in their mother language is a right whose protection issues in a collective benefit; the right itself applies to an identifiable group, and though particular individuals are beneficiaries, they are not rightholders; rather the group is the holder. This means that group rights involve a collective exercise (individuals exercise it on behalf of their group). The idea of a collective exercise and benefit implies that the group, as right-holder, has a normative dimension which is largely a function of shared understandings.

Members ... see themselves as normatively bound to each other such that each does not act simply for herself or himself but each plays her or his part in effectuating the shared normative understanding ... That there is such shared understanding is a matter of social fact and not merely a matter of legal assignment or ascription (McDonald, 1991:218-219).

The crucial criterion of being a group, and thus qualifying for group rights, is "a group-constituting understanding" (McDonald, 1991:219). Such an understanding is paradigmatically correlated to features like a shared heritage, language, belief, and social condition. People oppressed because of their ethnicity, race, or language provide a focus for a shared understanding. Deborah James (1997:123) observes in this regard that "experiences of domination and resistance in the colonial and apartheid eras ... have served as a basis for local identity-building in the present day". Let us call a group which has a "group-constituting understanding" an identifying community. Allegiance to an identifying community structures personal identity (at least, and minimally, partially) yielding content-full selves. In highly pluralistic contexts (for instance, South Africa), the self-identification of contentfull selves is non-voluntary and unchosen, at least initially - we identify with the identifying communities into which we are born. Voluntary identification comes later (the consequence, no doubt, of trans-acculturation), once we have acquired the necessary critical tools to make informed choices 
Complex equallty: some notes on redistribution in South Africa

As indicated above, with collective rights the community is the right-holder, which means that the community has moral standing, it defines the moral point of view in respect of rights pertaining to language and education. We should here distinguish between two separate moral contexts: the first is defined by a group-constituting understanding that makes an association into a community; the second is defined by the larger, pluralistic context in which one community stands as right-holder vis-à-vis another. In this second context collective rights pertaining to language and mother-tongue instruction should be equally available, i.e. equality should be the principle of distribution because this is required by the demand to redistribute recognition. But education is recognized as a needed good, and since rights to it are distributed according to need, historical injustices are corrected by awarding greater shares of the common wealth to the more needy. This means that former "black" schools in the former "black" territories have first claim on the public revenue, a claim clearly underscored by the demand for a redistribution of recognition. Collective rights essentially establish normative limits on the use of state power, and amounts to a guarantee of the identities of the various communities that make up the plurality of the state. To be a collective right-holder "contextually implies a certain confrontational stance" (McDonald, 1991:226) reminiscent of the understandings that are operative among indigenous peoples who have been confronted by aggressive and technologically advanced societies. A confrontational stance is attitudinal and not propositional, yet it is possible to discern a supporting justificatory thesis. According to this thesis group or collective rights protect "both interests and activities that cannot be otherwise protected. The interests that are protected are inherently collective or social interests, in particular the interest that human beings have in belonging to nurturing, identifying cultural groups" (McDonald, 1991:229).

\section{Mandela's natural rights theory}

Mandela's political philosophy, however, makes provision only for individual rights (Kalumba, 1995:161), in the sense in which natural rights theory defends them. An adequate view of this sense is given by Raz (1984:194). We can say some person $x$ "has a right if and only if $x$ can have rights, and other things being equal, an aspect of $x$ 's well-being (his interest) is a sufficient reason for holding some other person(s) to be under a duty". Of course, for someone to have a right in this sense, his or her well-being will have intrinsic worth, considered as an "endin-itself" (in the Kantian sense of requiring no further justification). An example of a right of this kind is the right to freedom of expression, which implies a corresponding obligation: holders of the right may not deny anyone freedom of expression, and no one has the authority to deny the rights-holder a similar (equal) freedom. All rights in the sense given above are said to ground duties, i.e, " $x$ 's possessing a right to $\mathrm{P}$ provides a reason for holding $\mathrm{Y}$ to be under an obligation, all other things being equal". Compare this view with the "reciprocity thesis" which Walzer defends. Walzer's emphasis on the particularity of (cultural) accounts of justice implies that rights are entitlements which must have 
institutional or social recognition to be claimed as entitlements. We have rights because we are members of (various) communities, but according to Mandela (Kalumba, 1995:162-164), rights are a fundamental feature of morality in the sense of being underived from any other (ultimate) interests, i.e. they are underived from our interest in being members of nurturing, identifying communities, so there can be no differences in what rights are accorded persons across communities Mandela recognizes negative and positive rights (Kalumba, 1995:162). Among negative rights, the basic ones comprise rights to life, liberty and justly acquired property; they are negative because the obligations that attach to them are those of non-interference (eg. the obligation not to kill others). Negative rights entail a certain view of the state: the role of the state tends to be defined in negative terms : the state is a mere umpire whose task is limited to securing non-interference in people's enjoyment of their negative rights. Positive rights call for obligations of provision, the necessities of life such as food, shelter and health care. Their recognition requires that the state assumes a bigger role: in addition to protecting basic negative rights, it has to implement basic positive rights as well - a role which may lead to it interfering with some people's basic negative rights.

Mandela's fundamental commitment - as judged from the Freedom Charter - puts him in the positive rights camp. The Freedom Charter includes rights demands which belong to the negative camp, but it also incorporates the basic necessities of life as rights. The right to being decently housed, the right of all to bring up their families in comfort and security, the right to be fed and to medical care are seen as entitlements which must receive a special emphasis and focus. Consider the terms in which Mandela phrases the ANC's demands: "a better health system which caters for all is not a privilege, but a right which must be guaranteed" (Mandela, 1995:53). "All communities have a right to housing" (Mandela, 1993:8-9). "Nationalization of mines, banks, and monopoly industry ... is a prerequisite of a fair distribution of wealth" (Mandela, 1995:173). The Freedom Charter does not call for the wholesale nationalization of business firms though it regards nationalization as an indispensable means for realizing the demands of the Charter.

It is true that in demanding the nationalization of the banks, the gold mines, and the land, the Charter strikes a fatal blow at the financial and gold-mining monopolies and farming interests that have for centuries plundered the country and condemned its people to servitude. But such a step is imperative because the realization of the Charter is inconceivable, in fact impossible, unless and until these monopolies are smashed and the national wealth of the country turned over to the people (Mandela, 1995:55).

But this is a matter of strategy rather than of principle. The ANC has "no ideological attachment to nationalization, but it's the only effective way to ensure an equal distribution of wealth. We say to the business community: if you have a better alternative tell us and if it's effective we'll abandon nationalization" (McCarton, 1991:11). 
Complex equallty: some notes on redistribution in South Africa

Nationalization is a weapon of the struggle.

The ANC has no blueprint that decrees that these or other assets will be nationalized, or that such nationalization would take this or the other form. But we do say that this option should also be part of the ongoing debate, subject to critical analysis as any other and viewed in the context of the realities of South African society (Mandela, 1990:2-63)

For Mandela, positive rights of provision are the ends to which nationalization is subordinate as the means (to overcome gross inequalities of wealth and rights between the races). Situated in the context of apartheid's inequalities, Mandela sees no alternative way of improving the situation of the disadvantaged majority short of tampering with private ownership of the means of production - the idea being to acquire the means to implement basic positive rights for the majority Neither the call for positive rights of provision nor the strategy to implement the call sees rights as founded in cultural communities.

\section{Need: the argument for group recognition}

Kymlicka (1989:903) argues that once we recognize the importance of the cultural structure and accept that there is a positive duty on the state to protect the cultural conditions which allow for informed choice, then cultural membership does have political salience. Becoming an informed chooser requires an identifying group (the context in which one acquires an identity) and recognition of one's language and culture. (Penalization and non-recognition result in marginalization and create barriers to the growth of autonomy.) Language and culture are, however, collective assets; their protection is best vested in identifying groups themselves. Individual rights alone are inadequate for the job in hand since they provide no protection against assimilation and negative modes of othering persons who are not members of the dominant group(s). Hence the need for collective rights to provide protection of the linguistic and cultural heritage of the members of distinct (minority) groups.

Iris Young (1990:45) explains marginalization as "structural and institutional relations that delimit people's material lives, including, but not restricted to, the resources they have access to and the concrete opportunities they have or do not have to develop and exercise their capacities". To experience cultural imperialism means "to experience how the dominant meanings of a society render the particular perspective of one's own group invisible at the same time as they stereotype one's group and mark it out as the Other" (Young, 1990:58-59) Cultural imperialism succeeds to the extent that a dominant group succeeds in bringing the other groups under the measure of their dominant norms (Young, 1990:59), thus disrupting and undermining other historical/traditional groupings, leaving individuals without other significant attachments or memberships. The net effect is one of disempowerment which impoverishes their very sense of agency. 
Only a politics of difference, which involves recognition of collective rights, can resist dominance and ensure a fair distribution of rights to language and education.

Besides the right to (mother-tongue) education, which has become a justified area of redistribution, there have been initiatives to identify health/medical care as a social good which must be distributed according to need (i.e. medical care should be available to all who need it irrespective of their ability to pay for it). And the motivation for this move springs from the recognition that a group identification of a kind is necessary, if only to justify a policy of differential awards. Walzer sees the justification as proceeding from communal interests, because "communal funds are spent ... to finance research, build hospitals, and pay the fees of doctors in private practice, the services that these expenditures underwrite must be equally available to all citizens" (Walzer, 1983:90), i.e. in accordance with their needs Walzer is careful to point out that a rich society which leaves provision of medical care to the free market is not necessarily unjust - the wealth of communities may be spent on "the cure of souls, not of bodies, or on defense, or drama, or education" (Walzer, 1983:44) as determined by the self-understandings of the relevant communities. Their priorities cannot be philosophically determined - only empirical research can establish that.

In South Africa justification follows lines consistent with Walzer's overall views that "whenever the purpose of communal provision is to open the way to communal participation, it will make sense to recommend a form of provision that is the same for all the members" (Walzer, 1983:78). The common life is a standard by which to judge social practices and communal provision of the kind in question and, as Downing and Thigpen (1986:463) put it, "bring citizens a heightened sense that they share a common life". In other words - failure to guarantee medical care in proportion to need constitutes evidence that the common life is poorly realized. We might argue that medical care is a social good in itself, and, following Downing and Thigpen (1986:402) maintain that all societies (rich and poor) should distribute this good in proportion to need. The grounds would be that modern medicine is a highly developed good which evolved through increased knowledge and technical competence and that all societies (especially rich, differentiated ones) place a high value on life and health, but this is not how this good is valued in South Africa.

\subsection{Other areas of justifiable redistribution}

\section{Public office}

Two other social goods, viz. public office and housing (among other commodities) should be redistributed according to principles currently being debated in South Africa. Following Walzer a public office is "any position in which the political community as a whole takes an interest, choosing the person who holds it or regulating the procedures by which he is chosen" (Walzer, 1983:129). Thigpen 
(1984:147-148) argues that Walzer's defence of complex equality “would check the universalization of office, as our [USA] values do not support the control of society by those who qualify according to whatever standards happen to be dominant". The acceptability of this view, as Thigpen (1984:148) points out, depends on Walzer's distinction between qualification and desert.

Walzer shows ... that qualification and desert are distinct concepts. Desert presupposes a strict entitlement that depends on something one has done. Unlike desert, which is backward-looking, qualifications are forward-looking. They depend on policy choices about the characteristics of persons that are needed for future performance in particular positions.

In South Africa decisions to distribute public office in accordance with population demographics qualify as such policy decisions. Decisions pertaining to in-service training for blacks aspiring to entrepreneurial positions in the large corporations is another case in point. The policy choices at issue here are again an expression of the demand for a redistribution of recognition. Walzer's concern, it should be remembered, is to secure an equality of participation rather than an equality of outcome, which means that these policy choices are aimed at securing the desired equality of participation.

\section{Housing}

A similar line of reasoning prevails with respect to a commodity like housing. Desert is not crucial to distribution in this sphere. Walzer believes that the outcome of market exchanges do not give persons what they deserve. Thigpen (1984:148) says the following of Walzer's view:

Market exchanges are based ... on the expectation of each party that he or she will benefit from the exchange. Without this expectation there can be no exchange. A person cannot deserve that others place the same values on a market exchange that he himself does ... if desert were to be relevant to the market, it would be necessary to specify a standard of work independent of what people want at a particular time. However, our [USA] understanding of the market forbids exactly such a standard of value.

So, what regulates participation in the market? Walzer thinks the principle of equal citizenship must prevail. People are aliens in their own country if they cannot buy goods at levels beyond what is necessary for bare subsistence. Commodities do not just have utility value - they are also needed for standing and identity. To ensure participation a minimal income must therefore be guaranteed to all citizens, and minimal must be defined as "beyond what is necessary for bare subsistence". Thigpen (1989:149) shows that again Walzer appeals to his notion of complex equality. "Complex equality emphasizes not that everyone should have the same amounts of money and commodities, but that those who have more should not also control other social goods." The appeal to complex equality, of course, places the open market squarely within the ambit of the common life. The common life - 
and, in particular, the right to equal participation in shaping the commonality, must be protected. This means that rights to participation in the market must be guaranteed. Complex equality would, of course, allow for inequalities within spheres, but not for their multiplication across different spheres. The best way to deal with domination is through blocking cross-boundary monopolies.

Complex equality means that no citizen's standing in one sphere or with regard to one social good can be undercut by his standing in some other sphere, with regard to some other good. Thus, citizen $x$ may be chosen over citizen $y$ for political office, and then the two of them will be unequal in the sphere of politics. But they will not be unequal generally so long as x's office gives him no advantages over $y$ in any other sphere - superior medical care, access to better schools for his children, entrepreneurial opportunities, and so on (Walzer, 1983:19).

\section{Shared understandings in South Africa: how deep do they run?}

\section{Land reform}

In some spheres, particularly income, wealth, and commodities, there is a deep cleavage in the thinking of South Africans which runs roughly along racial lines. Nozick's entitlement theory of distribution is often quoted in defence of historically acquired advantage. In Anarchy, state and utopia (1974) Nozick argues that any person whose holdings were initially justly acquired, and justly transferred (to succeeding generations), must be deemed to be in possesion of just holdings. Holdings are initially justly acquired if their acquisition does not worsen the position of the non-beneficiaries and provided that the latter retain the opportunity to improve their position. Thus, it may be argued, the appropriation of unowned holdings - such as the unexploited agricultural land of South Africa at the beginning of the 19th century by whites, and the transfer of these holdings largely by law of inheritance, were just in the sense that no-one was left worse-off, i.e. enough land as good as that which had been appropriated was left for others, and an increase in their holdings was not made more difficult to obtain. However, the Land Act of 1913 (amended in 1936) imposed statutary regulations affecting the freedom to own land in areas of an individual's choice, and assigned a disproportionally small area in total to blacks. This act had a direct impact not only on just acquisition, but also on just transfer (Klug, 1996:390-398). Blacks were made worse off, being unable both legally to improve their situation and to use and benefit from the land reserved for whites. So, though it may be argued that initial acquisition left no one worse off, after 1913 blacks in particular were not in the same situation as before. Redistribution, involving the transfer of land from whites to blacks, is therefore justified (Klug, 1996:398-401). Redistribution is a form of compensation, the aim being to raise those who have suffered injustice to the level before injust appropriations of holdings occurred. To this end the ANC government has formulated several acts - The Restitution of Land Rights Act (No. 
Complex equality: some notes on redistribution in South Africa

22 of 1994), The Labour Land Reform Tenants Act (No. 3 of 1996), The Communual Property Association Act (No. 28 of 1996) and The Interim Protection of Informal Land Right Acts (No. 31 of 1996).

\section{Industrial reform}

The South African situation is ridden by cross-cultural misrecognition and misinterpretation. On both sides of the black-white divide perceptions of the other as irreducibly "Other" require careful deconstruction. In the field of industry imploding the "partnership of the rider and the horse" - as the partnership of white capital and black labour have become known (Ngũgi wa Thiongo, 1993:118) would count as a great occasion worthy of celebration, provided that it is celebrated by past beneficiaries and non-beneficiaries alike. In this context the problem of redistribution is unlike the one obtaining in landholdings. The "struggle agenda" (James, 1997:127) focuses not on ownership of resources but rather on fair distribution of benefits. McNamara (1997:138-139) attributes the industrial unrest which has rocked South Africa since September 1973 - "the first contemporary strike by black mineworkers at Western Deep Levels mine" - to "a sense of shared discontent and moral outrage" among black mineworkers. The roots of their discontent and outrage were threefold: Racial discrimination in jobs (McNamara, 1997:145, 150), wage differentials between black and white workers (McNamara, 1997:146,15), and the emergence of a "proletarianized" black workforce - "men who no longer saw themselves as being tied to rural households, but were in their own view an industrial workforce" (McNamara, $1997: 148)$. It was this consciousness which enabled them successfully to mobilise protest action despite the presence of unique institutional labour controls on the mines (McNamara, 1997:150-151). The underlying principle of protest, defined by Ted Gurr (1970:352) and quoted by McNamara (1997:150), has emerged as a principle of (re)distribution based on shared understandings among the proletarianized workers. "If the [White-Capitalistic] elite is committed to progress ... the benefits of that progress should be evenly distributed. No group ... should gain less rapidly than others".

\section{Breaking down misrepresentations}

At the cultural level imploding the demarcation between the West "and the rest of us" (Ngûgĩ wa Thiongo, 1993:141) which so easily translates to "the Whites and the rest of us" means two things: First, Africa must rescue itself from its Dickensonian "Please Sir, can I have some more"-Third World posture (Ngũgi wa Thiongo, 1993:136). Second, "Out of Africa"-Whites must educate themselves to humane sensibilities - "What I learned from the game of the country was useful to me with my dealings with the native people" (Nguigi wa Thiongo, 1993:134 quoting Karen Blixen). Ngügi attacks the intemalization of a projected image, "What is ... often officially paraded as authentic African culture today is virtually a repeat of the colonial tradition ... acrobatic contortions emptied of the content of struggle" (Ngũgi wa Thiongo, 1993:27). Appiah (1992:72) echoes this sentiment. 
I ... worry about our entrancement with the polarities of identity and difference; partly because the rhetoric of alterity has too often meant the evacuation of specificity; partly because too many African intellectuals, captivated by this Western thematic, seek to fashion themselves as the (image of the) Other. We run the risk of an ersatz exoticism, like the tourist trinkets in the Gifte Shoppes of Lagos and Nairobi.

Deconstruction would involve re-educating formally colonised peoples to the pitfalls of over-valuing cultural artefacts coming from their erstwhile colonial masters (Wiredu \& Gyekye, 1992:62), and erstwhile masters learning that Africanness has less to do with a landmass and black skins than with people (Ki-Zerbo, 1975:61). Gyekye (1997:158) asks what the source of cross-cultural misrecognition is, and explains as follows:

If one were to look for a pervasive and fundamental concept in African socioethical thought generally - a concept that animates other intellectual ties and forms of behaviour ... and provides continuity, resilience, nourishment and meaning to life - that concept would most probably be humanism: a philosophy that sees human needs, interests, and dignity as of fundamental importance and concern.

The "partnership of the rider and the horse"-phenomenon is due to the failure of "technology transfer" to become "technology transplant" (Gyekye, 1997:285). Humanism, "the basis of African morality" (Gyekye, 1997:259) is the cause of Africa's pre-modem condition. "Technologicalization" (Gyekye, 1997:289) should be possible without its loss: the aim should be to remould society in such a manner that "the humanism of traditional African life reasserts itself in a modern technical community" (Gyekye, 1997:159).

\section{Neo-colonialism: Africa's millstone}

But, even as African philosophers ${ }^{1}$ view humanism as a counterbalance to Africa's structural dependence on a market-oriented West - as a platform for the advocacy of Afrocentrism - perceptions elsewhere decree that independence was cruelly limited in its effects: it narrowly privileged only the economic interests of the political class who effected liberation (Lazarus, 1995:12-13). Ngũgi, says Lazarus (1995:19-20), lays the blame for the West's prevailing Afro-pessimism before the failed attempts of "the African bourgeoisie to give meaningful freedom and independence to the broad masses of the people". Ngungi's picture of Africa, of a community struggling against a legacy of "colonial neglect and despoilation, postcolonial mismanagement and venality" (Lazarus, 1995:22), sees the contemporary African middle-class as the domestic arm of European neo-colonialism; it praises the horse, not its riders

I See Gyekye, (1997) and Wiredu (1996) 
Like other postcolonial nativist writers, Ngūgi continues to identify capitalism in Africa with neo-colonialism. Redistribution cannot be left to the open market, because the market favours those who already have the advantages. Money does not loose its colonising power, nor its class-specificity - money and its concommittant social power differentiations translate all too easily into political power - it is the root of a self-reproducing class system. Social control is nurtured in a class-governed model of society that detaches notions like equality from its determining material situations - in particular, situations of disadvantage which have grown up in the wake of colonialism. So detached, the idea of equal treatment (in the sense of all having equality of opportunity) becomes a means of justifying the specifics of a social stratification: as long as all are treated equally, the material speficities of social inequality appear to be legitimate because such inequality is perceived to be a consequence of the play of "fair rules" (i.e. rules which permit material inequality to grow alongside a formal legal equality). As a strategy for overcoming the social control exercised by capitalist, class-governed systems, moral categories of thought - equality, freedom and rights - should firmly be contextualised in the material circumstances of social life, and the meanings attached to them should be ones constructed in democratic discourses based on those circumstances. Understanding the real worth of each moral category is the first step in a remedial strategy which must remain open-ended: the social meanings of these categories must never be limited simply for the sake of social control.

\section{Shared understandings in South Africa: myth or reality?}

How does Walzer cope with cleavages of this kind and intensity in South Africa? Ingram (1995:139) sums up Walzer's view thus: "Walzer's point ... [is] that prior to any differences in opinion there are deeper, shared commitments to standards of justice". According to Ingram, Walzer denies that there can be conflicting interpretations of these deeper understandings because "Walzer's [interpretation] is based on a historical [approach]" (Ingram, 1995:139). Ingram (1995:139), however, argues that in Walzer's scheme of things "anticipation of meaning is itself incomplete, and remains relative to different contexts of interpretation (Ingram's emphasis). If correct there are no "deeper, shared commitments" of the kind Walzer supposes - only conflicts of interpretation about these commitments. The crucial point is, as Ingram (1995:139) notes, that neither a "context-presenttime-slice" nor an "historical narrative" which Walzer favours, can yield determinate answers. Ingram (1995:140) warns that appeal to some "allencompassing, theoretical account of justice beyond the conflicting, sphereimmanent accounts circulating in 'our' common understanding" tends to suppress both the sources of, and the different interpretations themselves of particular shared understandings. For instance though Nozick's theory throws some light on the South African problem, it is opposed to redistributions, treating them as instances of patterned distributions of the kind Walzer favours for distinct spheres. Patterned distributions necessitate redistribution whenever an existing distribution 
fails to conform to the predetermined pattern. Any system of justice and rights will generate patterned distributions in accordance with the provisions of the system in question. Nozick (1974:159-160) however, believes that social goods "come into the world already attached to people having entitlements over them", and, if initially justly acquired and justly transferred - according to the criteria Nozick favours - they are entitled to their holdings. At bottom Nozick's theory works on the principle of first come - first served (Cohen, 1986:129), a principle which fails to reckon with the cause of the problem in South Africa - viz, the exclusive membership policies of successive governments.

Yet South Africa needs historically-based, deep, shared understandings. It is a society which cannot afford to be politically divided because of economic interdependence. This fact had strengthened the hand of black "protest strategy" and had set in motion a process of "structuration" - of re-organizing the physical world of work and using it as a "habitus of power" capable of challenging the white-imposed structure of rules (McNamara, 1997:152). McNamara (1997:151) notes that mining "spawned an egalitarian work culture, best summarized by the worker phrase 'everyone gets dirty underground', which challenges the idea that some underground workers should enjoy more rewards than others". This "habitus" of egalitarianism "derived from peoples' conditions of experiences and position in the division of labour" (McNamara, 1997:151) offers a starting point for an understanding in the economic sphere - one which accords with a model for the political sphere which Walzer favours. Walzer (1997:12) recommends a model of the state without a dominanant cultural majority which he calls the "immigrant" society. An immigrant society has no majority and therefore no minorities - there is no group whose culture is the official culture and whose language is the national language. However, successful parallel coexistence of communities with distinct beliefs, values and practices is premissed on shared social meanings and a public history, things requiring treatment which makes it legitimate "to tell stories about the history of diversity and to celebrate its great occasions" (Walzer, 1997:37). The immigrant model makes it possible for every constituency to share the public sphere on equal terms - and to tell their own versions of the national history.

The voices "coming out of centres outside Europe" (Cantalupa, 1995:210 quoting Ngügi 1993) speak of structures of "domination and subjugation" (Cantalupa, 1995:224) of peoples' "lack of empowerment" (Cantalupa, 1995:212) and of desires for "moving towards a pluralism of cultures, literatures and languages" (Ngügi" 1993:10) and wanting to understand "all the voices coming from what is essentially a plurality of centres all over the world" (Ngügi", 1993:11). It is towards this vision that the struggle for recognition is directed. These are some of the dominant voices being heard in South Africa today. They conflict with voices - Nozickian in tone - coming from less numerous but still powerful interest groups intent on resisting redistribution. 


\section{List of references}

APPIAH K A 1992 In my father's house. Oxford : Oxford University Press

BELL, D. 1993. Communitarianism and its critics. Oxford : Clarendon Press.

CANTALUPA, C 1995. Moving the centre: an interview by Charles Cantalupa. (In Cantalupa,

$\mathrm{C}$ ed The world of Ngugi wa Thiongo. New Jersey : Africa World Press. p. 207-227.)

COHEN, G.A. 1986. Self-ownership, world-ownership, and equality. (In Lucash, F.S. ed. Justice and equality here and now. Ithaca : Cornell University Press p. 108-135.)

DOWNING, LA \& THIGPEN, R.B 1986. Beyond shared understandings Political Theory, 4(3):451-472

GURR, T. 1997. Why men rebel. Princeton : Princeton University Press.

GYEKYE, K. 1997. Tradition and modernity. Oxford : Oxford University Press.

INGRAM, D 1995. Reason, history, and politics. New York : State University of New York Press.

JAMES, D. 1997 Anthropology, history, and the making of past and place (In McAllister, P. ed Culture and the common place. Johannesburg : Witwatersrand University Press. p 115-136)

KALUMBA, KM 1995. The political philosophy of Nelson Mandela: a primer. Journal of Social Philosophy, 26(3):161-171.

KI-ZERBO, J, 1975. African personality and the new African society. (In Mutiso, G.M. \& Rohio, S.W eds. Readings in African political thought. London : Heinemann. p. 339-343.)

KLUG, H. 1996 Historical claims and the right to restitution. (In Van Zyl, J. et al. eds Agricultural land reform in South Africa. Cape Town : Oxford University Press. p. 390-412.)

KYMLICKA, W 1989. Liberalism and communitarianism. Canadian Journal of Philosophy, 18(2): 181-204.

LAZARUS, N. 1995. (Re)turn to the people: Ngûgi Wa Thiongo and the crisis of postcolonial African intellectualism. (In Cantalupa, C. ed. The world of Ngügi Wa Thingo. New Jersey Africa World Press. p 11-25.)

MANDELA, N. 1990. Speeches 1990: intensify the struggle to abolish apartheid New York: Pathfinder Press.

MANDELA, N 1993 Statement of the executive committee. The Militant. 8-11, Jan 29.

MANDELA, N. 1995. The struggle is my life. New York : Pathfinder Press.

McCARTON, G. 1991 Mandela: S. Africa violence caused by apartheid regime. The Militant 7-13, Nov. 1.

McDONALD, M. 1991. Should communities have rights? Reflections on liberal pluralism. Canadian Journal of Low and Jurisprudence, IV(2):217-237.

McNAMARA, K 1997. Culture, consciousness and change (In McAllister, P. ed. Culture and the common place. Johannesburg: Witwatersrand University Press. p. 137-155.)

NGũGi' Wa THIONGO. 1993. Moving the centre. London: James Curry.

NOZICK, R. 1974. Anarchy, state and utopia. New York : Basic Books

THIGPEN, R.B. 1984. Michael Walzer's political theory of the common life The Political Science Reviewer, xiv: 133-163

RAZ, J. 1984 On the nature of rights. Mind, 93:194-214.

YOUNG, I. 1990 Justice and the politics of difference. Princeton : Princeton University Press

WALZER, M. 1983. Spheres of justice. New York : Basic Books.

WALZER, M. 1987. Interpretation and social criticism. (In McCurrin, S.M. ed The Tanner lectures on human values. Oxford : Oxford University Press. p 1-80.)

WALZER, M. 1997. On toleration. New York : Basic Books

WIREDU, K. 1996 Cultural universals and particulars Indiana : Indiana University Press 